\title{
The Advanced Hydraulic City Structure of the Royal City of Angkor Thom and Vicinity Revealed through a High-Resolution Red Relief Image Map
}

\author{
Shimoda Ichita1, Haraguchi Tsuyoshi' ${ }^{2}$, Chiba Tatsuro ${ }^{3}$, Shimoda Mariko ${ }^{4}$ \\ ${ }^{1}$ World Heritage Studies, Graduate School of Comprehensive Human Sciences, University of Tsukuba, \\ Ibaraki, Japan \\ ${ }^{2}$ Graduate School of Science Biology and Geosciences, Osaka City University, Osaka, Japan \\ ${ }^{3}$ Asia Air Survey Co., LTD., Kawasaki, Japan \\ ${ }^{4}$ Waseda Research Institute for Science and Engineering, Tokyo, Japan \\ Email: ichita731@hotmail.com
}

Received 6 November 2015; accepted 2 January 2016; published 5 January 2016

Copyright (C) 2016 by authors and Scientific Research Publishing Inc.

This work is licensed under the Creative Commons Attribution International License (CC BY).

http://creativecommons.org/licenses/by/4.0/

(c) (i) Open Access

\begin{abstract}
Numerical topographic data acquired through airborne laser scanning (LiDAR) performed at the Angkor Archaeological Park in Cambodia in April 2012 has revealed a large number of heretofore obscured water channels and ponds (Evans et al., 2013). Using this data, a high-resolution red relief image map (RRIM) was created of areas inside and outside the moated royal capital of Angkor Thom built during the latter half of the 12 th century. The land around Angkor Thom is extensively covered by tropical jungle which has relatively well preserved the original urban structures and middle/post-Angkorian period modifications and renovations by escaping human-induced surface alteration except for the tourism-related infrastructure and renovations from the 20th century onward. The RRIM provided a new visualization method of localizing, minute topographical changes in regions with large undulations over a wide area. It has proved to be effective in mapping, on a single wide-area map, the numerous buried remains that exist as comparable height differences or minute undulations measuring less than 1 meter in height, and provides a unique aerial view of their widespread distribution. Based on the RRIM map, past archaeological studies were referenced to reconstruct the layout of the water channel network system. Past studies revealed that a large number of ponds had been dug inside Angkor Thom. The RRIM expanded the investigation and revealed the existence of many ponds outside the royal capital indicating that a residential community had flourished outside the moat-surrounded capital city. This paper was discussed the functional aspects of the water channel network and ponds that utilized the gentle gradient of the natural land to overcome the climatic induced environmental changes that were characterized by an extreme divide between the rainy and dry seasons.
\end{abstract}




\section{Keywords}

\section{Airborne Laser Scanning, Visualization, Urbanism, Water Management, Khmer}

\section{Introduction}

The royal capital of Angkor Thom, built by Jayavarman VII in the latter half of the $12^{\text {th }}$ century, lies in the tropical forest of the Angkor Archaeological Park. The royal city, surrounded by a $3 \mathrm{~km}$-square enclosure and moat, was developed as the center of the Angkor Empire's expansive territory. Included within its walls are Bayon temple, situated in the center of the city, and numerous stone temples, royal palace ruins and a royal plaza, including buildings built in periods before and after the initial construction of the royal capital.

The Khmer Archaeology LiDAR Consortium, composed of a team of international researchers, utilized airborne laser scanning (LiDAR) technology to survey an area of $370 \mathrm{~km}^{2}$ in April 2012 that included the Angkor Archaeological Park, the Koh Ker site, and part of Mt. Kulen. As a result, it was found a large number of hydraulic structures including water channels and ponds previously not identified as land features inside and outside the dense forest of Angkor Thom (Evans et al., 2013). The authors used a topographical data processing technology called Red Relief Image Map (RRIM) to map the topographical features of the Angkor area so the features could be more visually recognizable. A map was produced that allowed minute land features to be identified where they could not be identified from conventional contour maps, color contour maps, and shaded reliefs. The map also provided an aerial view of minute land features over the entire survey area. Capturing subtle undulations in the present landscape created by remains that lay buried over a wide area proved to be extremely effective in assessing the shape, layout and interrelationship of hydraulic structures, and other such structural elements. This paper discusses the hydraulic structures in and around Angkor Thom which have come to light through the RRIM interpretation.

\section{Method of Creating a RRIM}

From the LiDAR digital elevation model (DEM) a three dimensional visualization method known as Red Relief Image Map or RRIM was produced effectively representing 3D topographic information without any additional devices and stereopsis ability for its audience (Chiba et al., 2008). The RRIM was originally developed for visualization of DEMs produced by LiDAR, but is also suitable for a wide variety of such high resolution three dimensional data such as SRTM, GTOPO30 and ETOPO2. This method can visualize the topographic slope, concavities and convexities at the same time. The RRIM combines an image that expresses slope by different intensities of red and an image that expresses altitude by brightness; areas are redder as the gradient becomes steeper, areas near ridges are brighter the closer they are to the ridge, and valleys are darker the deeper they become. Height and depth, or ridges and valleys, are obtained by subtracting underground openness from aboveground openness and dividing the remainder by 2 . Overground and underground openness are parameters proposed by Yokoyama (2002), which take into consideration the fractal nature of the terrain and adjust images to match the upper size limit of the terrain that is to be mapped. One of the advantages of the RRIM is that it can clearly visualize localized, subtle topographical changes even in regions with large undulations over a wide area. In other words, the RRIM represents not only large-scale land features but also fine structures in a wide variety of topographic situations.

From the high-resolution RRIM vestiges of a large number of ponds, linear water channels and mounds were identified inside and outside Angkor Thom (Figure 1). Included among them were many remains that could not have been identified from conventional contour maps, color contour maps and shaded reliefs. The RRIM was particularly effective in identifying the accurate shapes of small ponds, narrow water channels and levees. As Angkor Thom is situated on land that gradually slopes downward from the northeast to the southwest, the detailed landform of the entire area could not be expressed evenly on a multicolor contour/shaded relief map, but the RRIM was highly useful in detecting and analyzing the functions of buried features that exist as height differences of several meters or subtle undulations measuring smaller than 1 meter in height throughout the entire city (Figure 2).

The vestiges of ponds and water channels that were confirmed have remained in relatively good condition in 


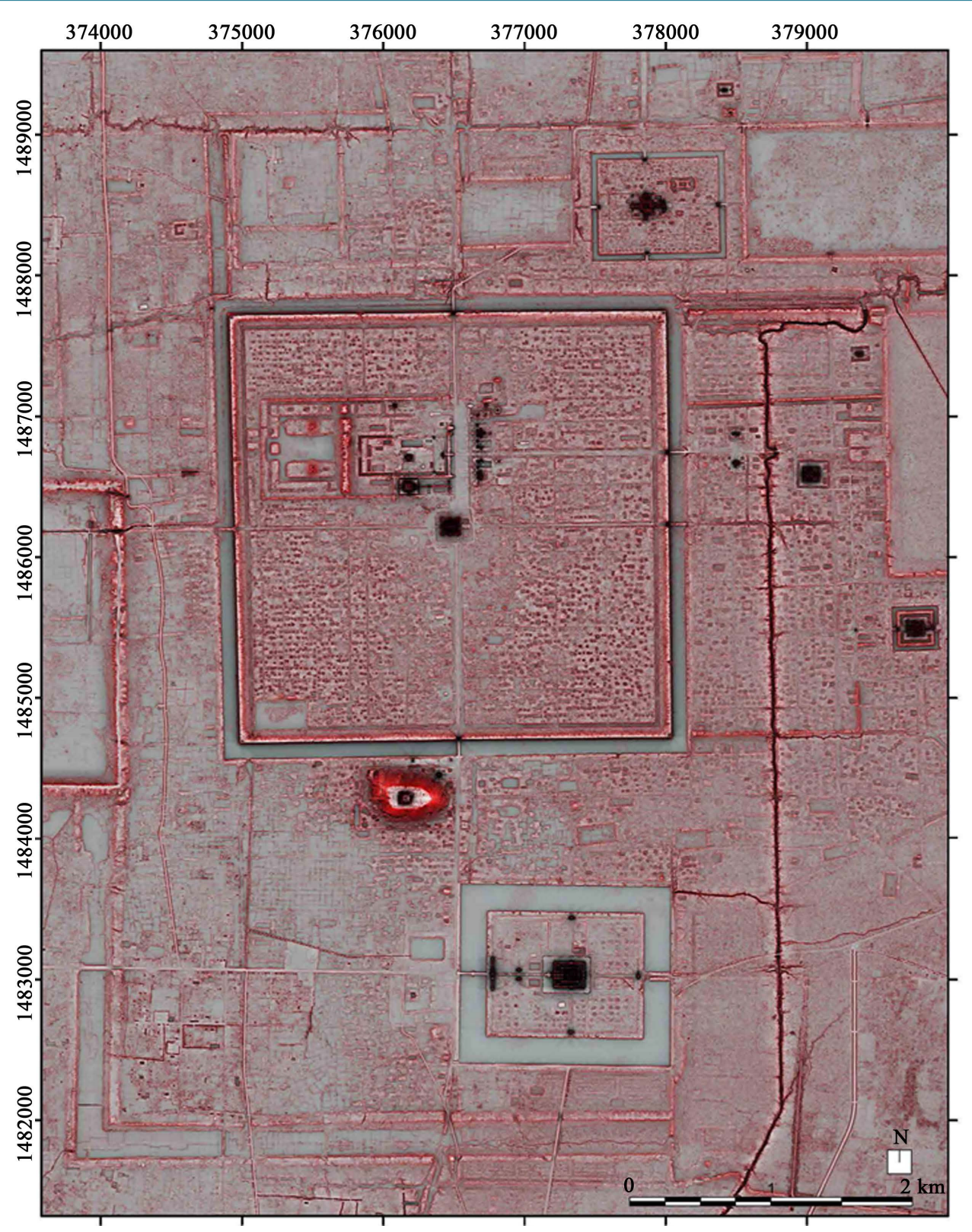

Figure 1. High-resolution RRIM of the central area of the Angkor Archaeological Park.

the dense forest (Figure 3). The fact that they were hidden in the forest prevented them from human-induced topographical alterations caused by paddy field reclamation and village formation. In contrast, vestiges in older rice paddies and farmland have mostly been lost due to disturbance of the ground surface and leveling of the terrain. In this study, a $61.8 \mathrm{~km}^{2}$ central area of Angkor, where large numbers of remains have been found, was mapped (Figure 1, Figure 3 and Figure 4). Of this area, dense forest covers $24.7 \mathrm{~km}^{2}$ and obscures many ponds, water channels and mounds.

\section{Summary of the Past Studies on the Hydraulic Structure of the Angkor Thom}

Aside from the principal stone structural remains at the central area of Angkor Thom, numerous ancillary remains and hydraulic facilities are scattered in the moated city. The study of such remains, including water channels was commenced by Marchal in 1917, and was thereafter continued by Trouvé, Goloubew, and Glaize. In more recent years, Gaucher has greatly advanced the study. 

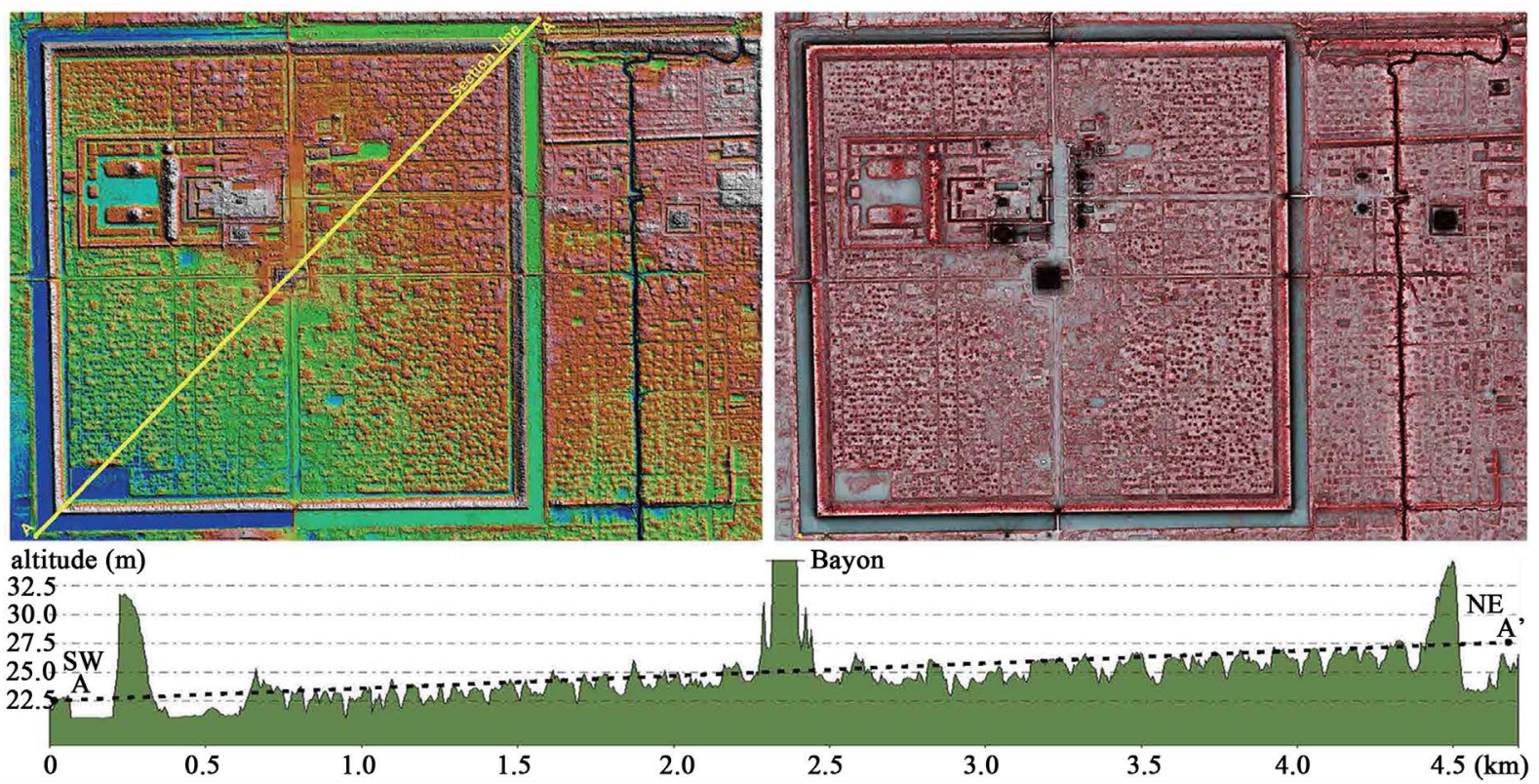

Figure 2. Comparison of color shaded relief map (left) and RRIM (right) for the Angkor Thom and east area, and section through northeast to southwest of Angkor Thom (bottom).

Marchal conducted a study of Buddhist terraces in Angkor Thom and Prasat Chrung of which there are four located in the four corners of the enclosure of the royal city (Marchal, 1918, 1925). Trouvé conducted a study of the water channel network around Angkor Thom (Trouvé, 1933) which was later complemented by a study by Groslier that accompanied an aerial survey and revealed the relationship of the water channel network with water channels and baray reservoirs in the vicinity of the royal city (Groslier, 1958). Goloubew conducted an excavation survey in various areas within Angkor Thom and uncovered the existence of a number of water channels (Goloubew, 1933, 1934, 1936, 1937). He also shed light on the existence of another moat inside the enclosure, and suggested the possibility that it surrounded the city preceding the construction of the royal city whose ruins exist today. Glaize conducted an excavation survey of the Buddhist terrace that was reported by Marchal and uncovered its details (Glaize, 1937). Gaucher commenced a study of Angkor Thom a half century later, and provided a comprehensive study that made full use of topographical surveys, subsurface explorations, and archaeological excavations (Gaucher, 1997, 2002, 2003, 2004a, 2004b).

The present landform inside the royal capital displays not only the initial structure at the time of construction of the royal capital in the latter half of the 12th century, but also a multilayered structure of various works from periods before and after. As Groslier put it in the past, the Angkor Monuments are a palimpsest, and require exhaustive archaeological excavation surveys to elucidate. However, even while the monuments pose difficult conditions, the hydraulic structure of Angkor Thom is gradually being revealed through the abovementioned past studies.

\section{Hydraulic Structure in the Angkor Thom}

Angkor Thom is a square plot of land measuring approximately $3 \mathrm{~km}$ on each side that corresponds to the cardinal directions, and is surrounded by a moat that is roughly $110 \mathrm{~m}$ wide with an enclosing wall on the inside of the moat. The moat is divided into five sections by approaches that extend from each of the five gates. No water channels have been found that interconnect the sections.

Based on past studies the moat water is drawn into the enclosing wall from tunnels located $80 \mathrm{~m}$ south of the northern end of the east side of the enclosure. No other external water intake structure has been found, and precipitation and underground water are the only other source of water to the interior of the moated city. The tunnels are supported by a corbel arch structure. There are four tunnels that lie side-by-side, each measuring approximately $68 \mathrm{~m}$ long (Goloubew, 1936). Through these tunnels water impounded in the outer moat was drawn into the internal linear structure. 


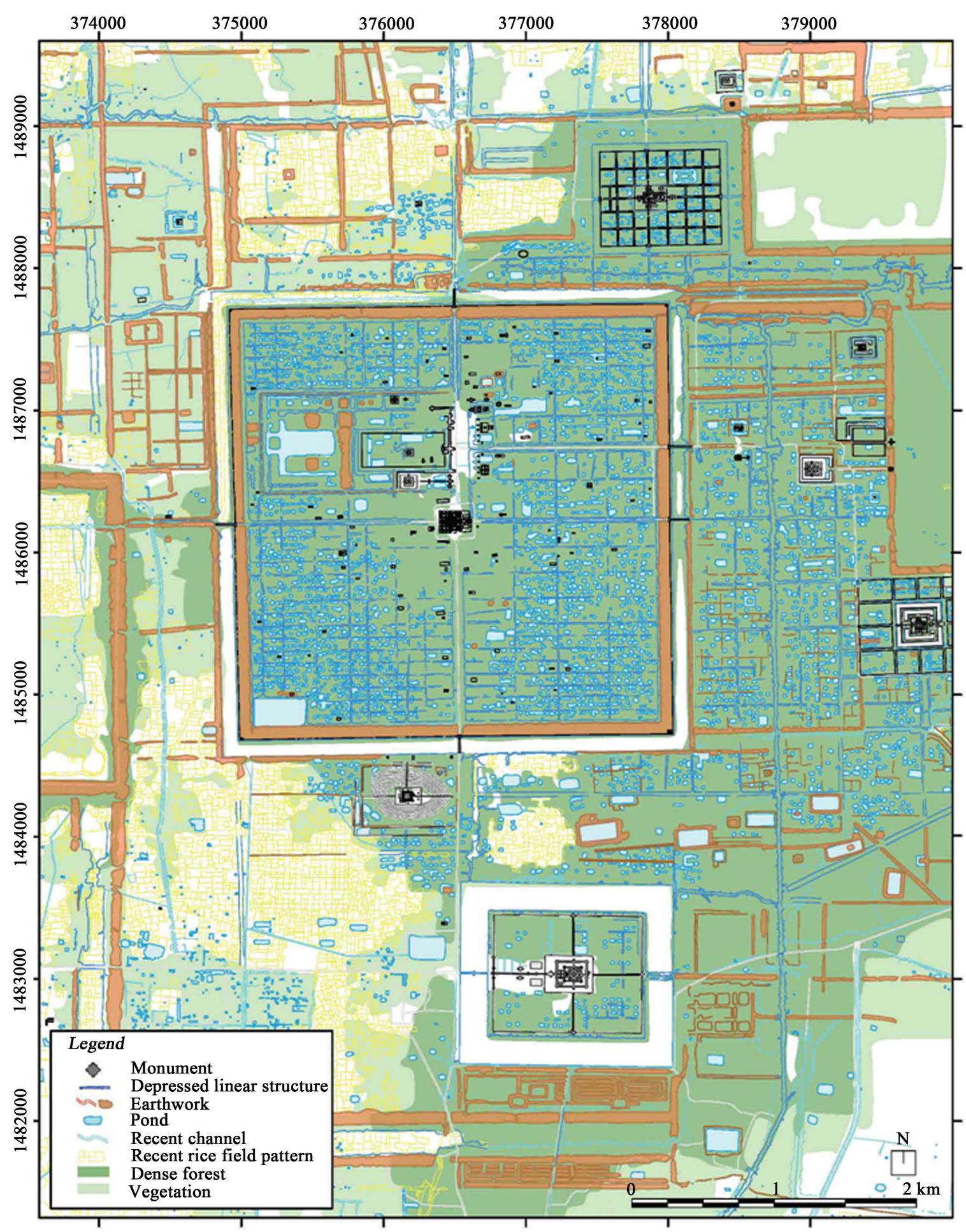

Figure 3. Map of the present state of the central area of the Angkor Archaeological Park. The distribution of monuments in Angkor Thom is based on Gaucher (2004b). Depressed linear structures, earthwork, ponds and recent rice field patterns are identified in the RRIM map. The distribution of dense forest and vegetation is shown based on satellite photo. While many depressed linear structures and ponds can be confirmed in the dense forest, no such vestiges were found in wet-rice cultivation fields. The distinction between new and old water channels (depressed linear structures and recent channels) includes channels that are difficult to decipher at present. In particular, it should be noted that there are cases where a new water channel was built using a water channel that existed during the Angkor period. 


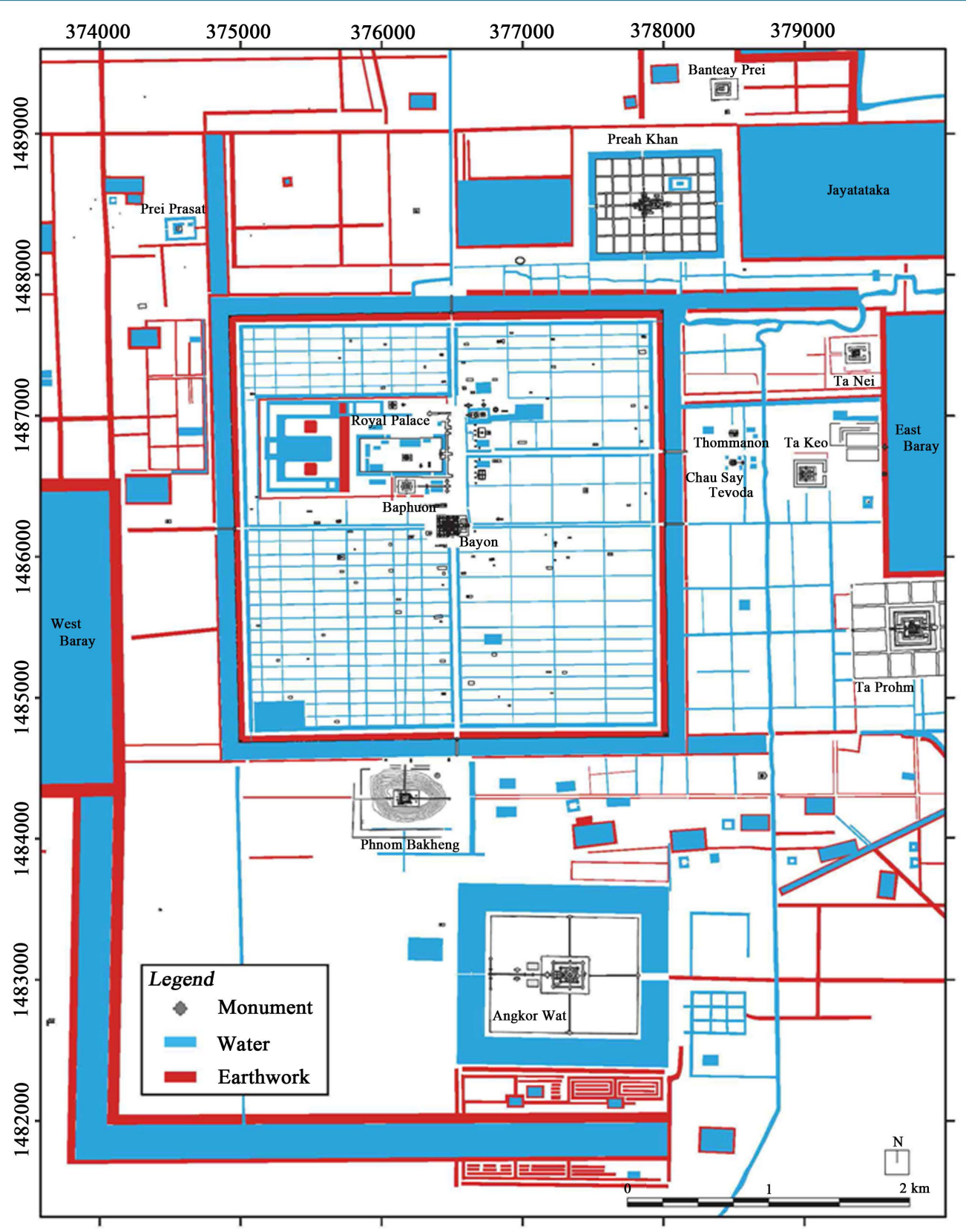

Figure 4. Reconstruction of water channels and earthworks in the central area of the Angkor Archaeological Park.

The internal linear structure is located 80 - $100 \mathrm{~m}$ inside the enclosure. Excavation surveys have found that it is bounded by a tiered embankment made of sandstone upper tiers and laterite lower tiers. Measured at the topmost tier of the embankment, the moat is $24-28 \mathrm{~m}$ wide and the embankment is $2.2 \mathrm{~m}$ high. As with the moat on the outside of the enclosure, the internal linear structure is also interrupted by five large approaches extending from the Bayon and the Elephant Terrace, and past excavation surveys have revealed that they are connected by culverts below the approaches at least on the inside of the East Gate, Gate of Victory and the South Gate (Goloubew, 1936). However, in the excavation of the northwest corner of the internal linear structure, a structure that blocks this linear structure was found. A similar structure was found in the southwest corner. It was presumed that the west side of the internal linear structure does not connect with the Beng Thom reservoir in the interior of the city. Thus, any judgment about whether the internal linear structure was continuous full must wait for further investigations. 
Parts of water channel-like structures have been confirmed in excavation and boring surveys conducted on the sides of the five main approaches (Goloubew, 1933, 1934; Gaucher, 2004b). However, widths and structural materials that are different have been found from the left and right sides of each approach. Furthermore, structures that divide these water channel-like structures were found in several locations. It was also confirmed that they do not connect with the internal linear structure. When considering these findings, it seems reasonable to propose that the structures were not part of a continuous water channel, but rather narrow reservoirs or temporary holding features.

In addition to the channel-like structure along the main approaches and internal linear structure, the possibility had already been pointed out that a water channel network existed throughout the moated city (Groslier, 1958). However, any attempt to reveal such a structure has been abandoned for a long time because the dense forest prevented aerial surveys, and surface surveys were difficult to conduct. Against this backdrop, the existence of a water channel network displaying an irregular grid pattern was revealed by Gaucher. According to excavation surveys, the grid pattern water channel and internal linear structure are interconnected (Gaucher, 2004b), and thus the water channels probably ensured a continuous flow of water. At the same time, however, water channel-like structures along the main approaches have also been found divided into smaller parts. Therefore, any discussion on the control of flowing water at the intersections of the water channel network and the continuity of the water channels requires further archaeological studies.

It is proposed that the flow of water through the water channel network in the moated city ultimately converged and pooled in the Beng Thom reservoir in the southwest corner in the enclosure. However, the connection relationship of the internal linear structure and grid pattern water channels with Beng Thom is still uncertain. Beng Thom measures $193 \mathrm{~m}$ in the north-south direction and $380 \mathrm{~m}$ in the east-west direction. At present, it is only approximately $1.5 \mathrm{~m}$ in depth, and the results of a boring survey conducted in 2007 revealed that the bottom sediment is around $50 \mathrm{~cm}$ (Mori, 2012). Thus, it is assumed that water storage capacity was limited.

The impounded water in Beng Thom was drained to the moat through five tunnels that pass through the western end of the south side of the enclosure. They have the same corbel arch structure as the water intake tunnels in the northeast corner and approximately $58 \mathrm{~m}$ in length (Marchal, 1918). The bottom level of the southern end of the west side of the internal linear structure is $2.3 \mathrm{~m}$ lower than that of the moat, and the tunnels display a gentle downward slope toward the city so it is proposed that water was not drained into the moat unless the water level in the internal linear structure reached a certain level.

\subsection{Reexamination of the Grid Pattern Structure}

Data accumulated through past excavation surveys have gradually clarified the layout of water channels in the moated city, and new topographical data has verified their overall layout structure. When including the water channel-like structures along the main approaches, the irregular grid pattern of channels, and internal linear structure, the water channels extend a total length of $95 \mathrm{~km}$ within the royal city.

Figure 3 shows a relief of the present land features that represent vestiges of water channels and embankments based on the RRIM. This figure was created by manual vectorization of the outline of each artificial structure; “depressed linear structure”, “earthwork”, “pond”, “recent channel” and "recent rice field pattern”. The grid pattern in the moated city is formed by a series of depressions and embankments, but it is believed that the areas in the grid were depressions, or water channels. The majority of linear traces of depressions were 5 $10 \mathrm{~m}$ in width, but those at grids labeledW2S, W4S, W5S, W4N, and W5N were a slightly wider at 13 - $15 \mathrm{~m}$, and not uniform.

Figure 4 shows a proposed conjectured layout of water channels and embankments inside and outside of Angkor Thom utilizing Figure 3. The new map corresponds in large part to a previous report by Gaucher, and validates that Gaucher's work was based on a reasonably accurate survey. Even so, there are some elements that differ from his result. For example, in the northern half of the southeast quadrant, Gaucher has identified water channels that run in the east-west direction in the same manner as the southwest quadrant (Figure 5: S1E, S3E, S5E, S7E), but no vestiges of such structures are evident in the RRIM. Furthermore, Gaucher identifies a water channel that extends in the north-south direction at the eastern edge of the southeast quadrant (Figure 5: E5S). As there are clear vestiges in the northeast quadrant, the water channel could have extended from here, but no vestiges are apparent in the RRIM. It is also difficult to state with certainty that anthropogenic structures had necessarily existed at W2N, N2W and N4E. Moreover, Gaucher interpreted W5N in the northwest quadrant as two rows of linear structures, but using the RRIM any differences with other linear structures is vague. 


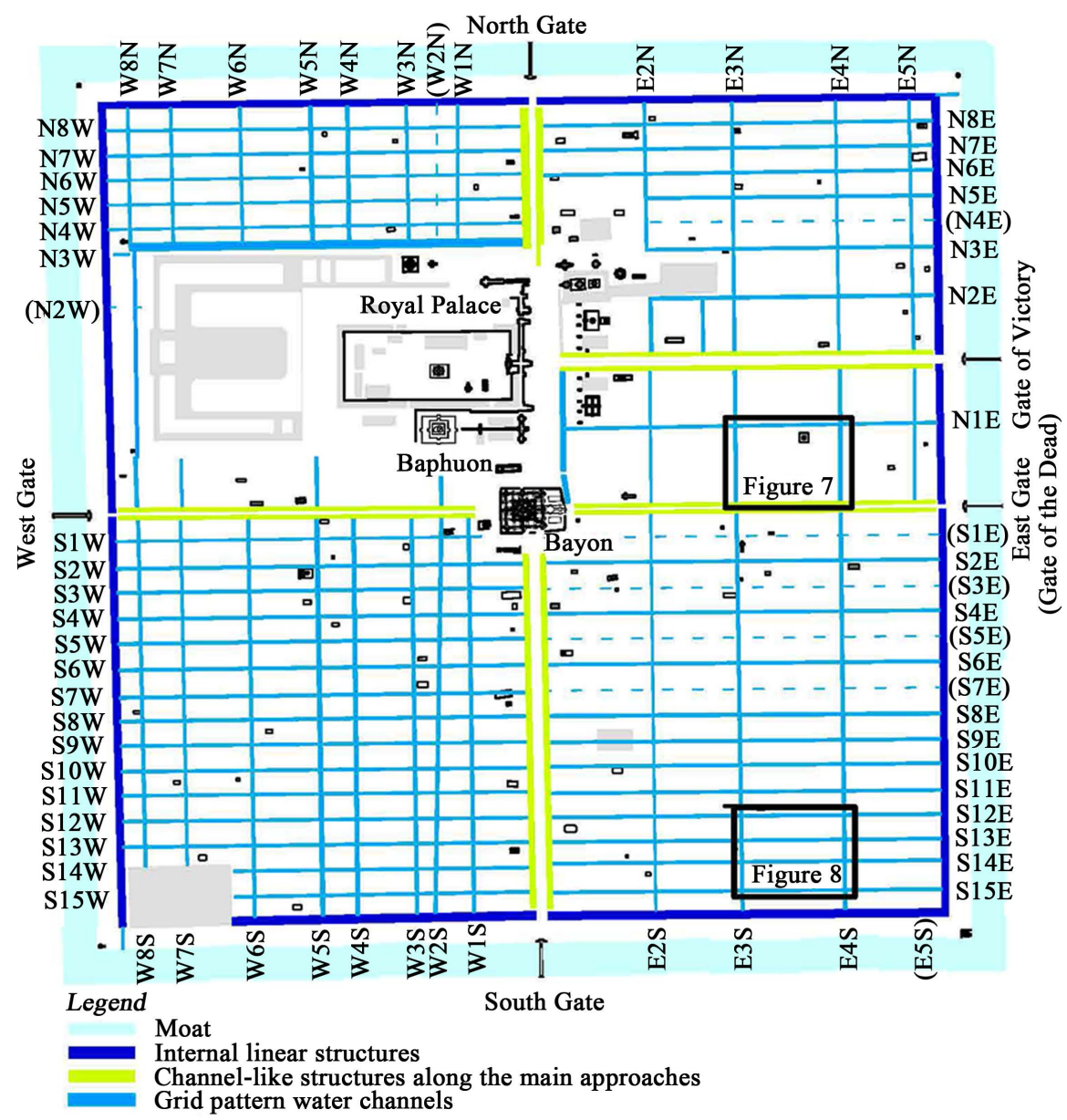

Figure 5. Layout of water channels in Angkor Thom. The coding of the grid pattern of the water channel network is according to Gaucher (2004b), but codes in parentheses indicate grids that could not be verified in the new topographical data.

\subsection{Ponds in the Moated City}

Among the hydraulic features in the moated city, the numerous ponds are important elements in addition to water channels. Gaucher counted a total of 2895 ponds (Gaucher, 2004b). They include Beng Thom and other large ponds, but most are less than $1000 \mathrm{~m}^{2}$. The ponds generally have a ground plan that is rectangularly long in the east-west direction, with the long side measuring $20-40 \mathrm{~m}$ and short side measuring around $20 \mathrm{~m}$. In terms of depth, many are around $1-2 \mathrm{~m}$ as present land features (Figure 6, Table 1). Ponds in the southeast quadrant are relatively deeper than the other areas. However, future survey is essential to elucidate the depth of the initial pond bottom located beneath the sedimentary soil.

The ponds are deformed due to long years of erosion, soil and sand deposits. The new topographical map has confirmed the outlines of roughly 2000 ponds in the royal city (Table 1). This figure differs from Gaucher's figure, but the new figure counts adjacent ponds that have become a single pool as one, and does not count ponds near the main approaches extending to the south and north from Bayon whose traces are unclear. Figure 7 shows how difficult it is to identify the initial shape of ponds by comparing, for example, the area around the four water channels of NOE, N1E, E3N, and E4N according to Gaucher's distribution map and the RRIM.

Ponds are particularly densely distribution in the southeast area of the royal city. In the three areas surrounded by water channels E3S, E4S, S12E, and S15E, measuring $350 \mathrm{~m}$ east to west and $260 \mathrm{~m}$ north to south, there are 51 ponds in a total area of $91,000 \mathrm{~m}^{2}$, such that approximately $28 \%$ or $25,350 \mathrm{~m}^{2}$ of the site is covered by ponds (Figure 8). The ponds are frequently located as though to form a continuous row in the east-west direction. They probably took on this elongated shape due to the later addition that overlapped with existing ponds. 


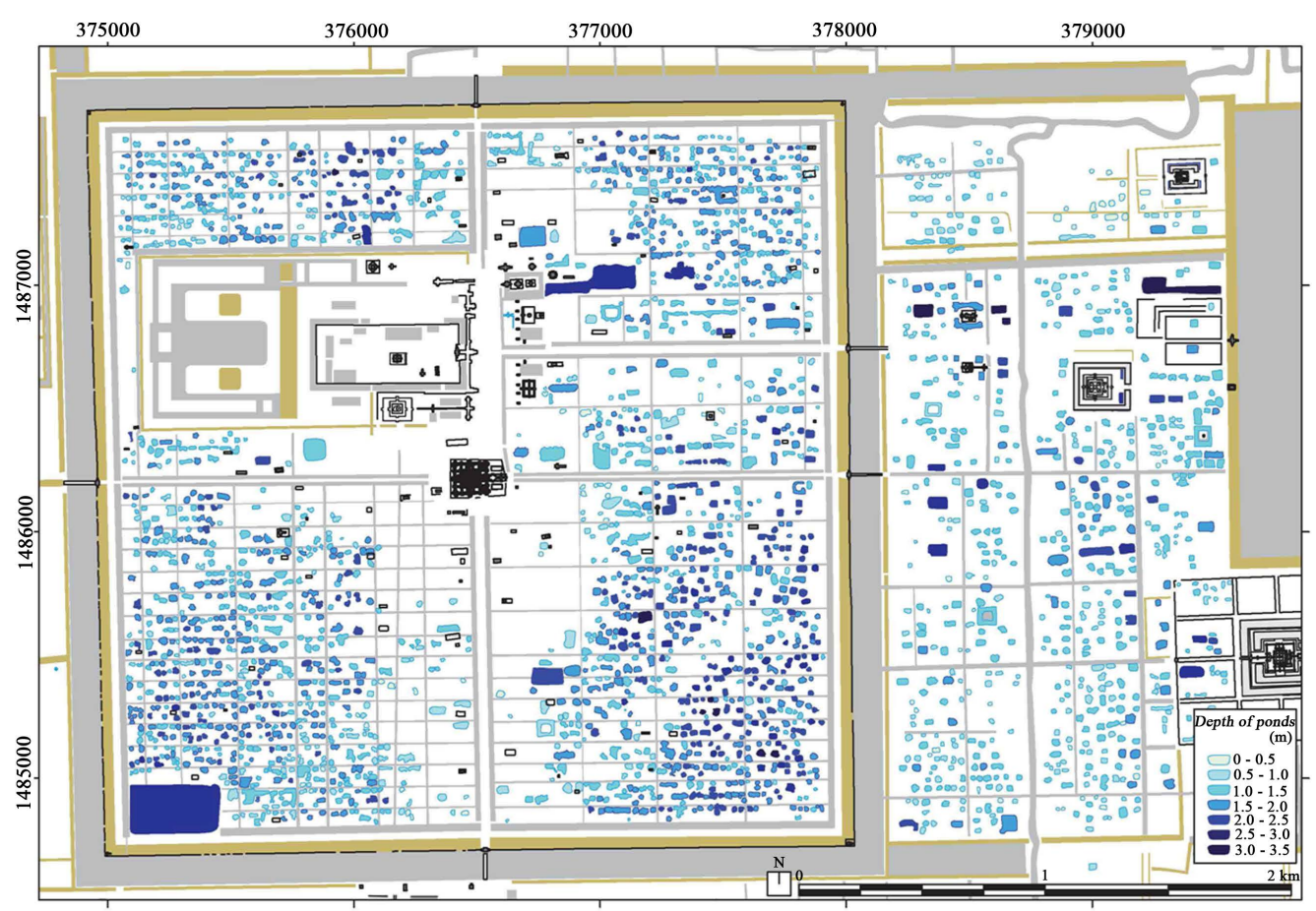

Figure 6. Distribution of ponds by different depth for the Angkor Thom and east area.
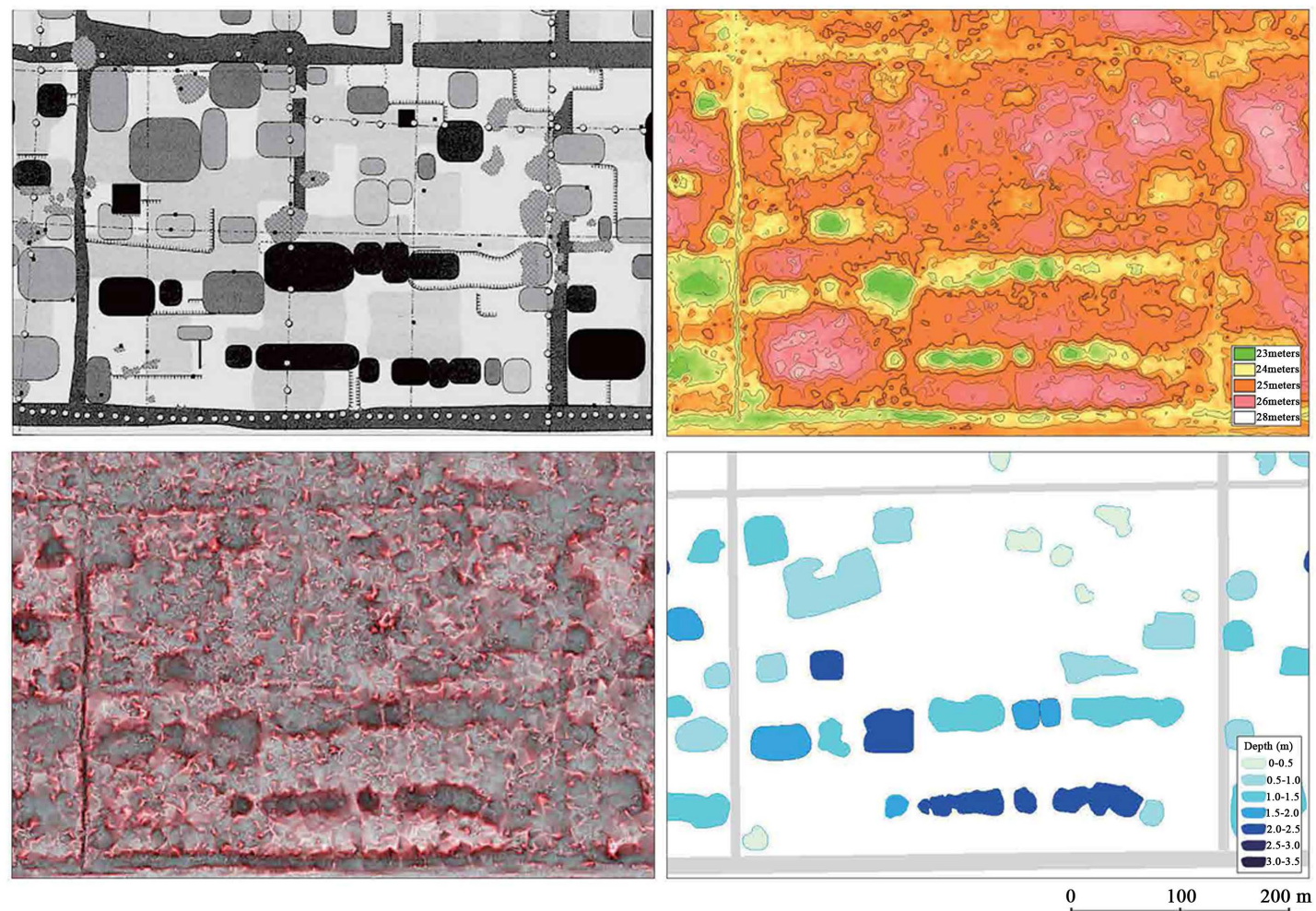

Figure 7. Distribution of ponds in a specific area of Angkor Thom surrounded by water channels. The location of this area is shown in Figure 5. In this area, it is particularly difficult to distinguish the shape of each pond, as it is thought that ponds were dug overlapping each other, and also due to erosion and sedimentation. (Above left: Gaucher, 2004a, Figure 17; above right: Shaded relief and contour lines $(1 \mathrm{~m})$ based on LiDAR data; below left: High-resolution RRIM; below right: Reconstruction of ponds from High-resolution RRIM). 

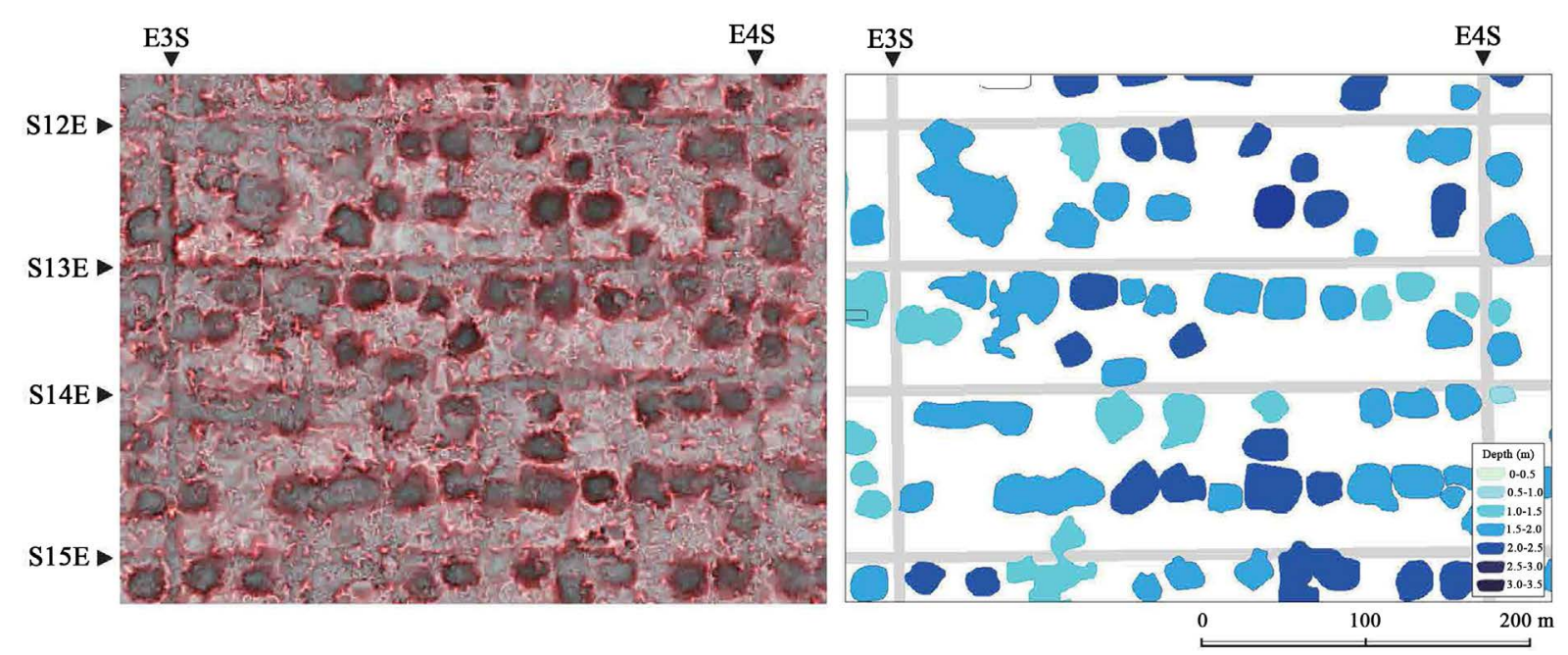

Figure 8. High-resolution RRIM (right) and reconstruction of ponds (left) of three sections in the southeast quadrant of Angkor Thom surrounded by S12E, S15E, E3S, and E4S. The location of this area is shown in Figure 5. The area has a particularly dense distribution of ponds. In fact, $28 \%$ of the area is ponds.

Table 1. Number of the ponds by the different depth in each area inside and outside the Angkor Thom.

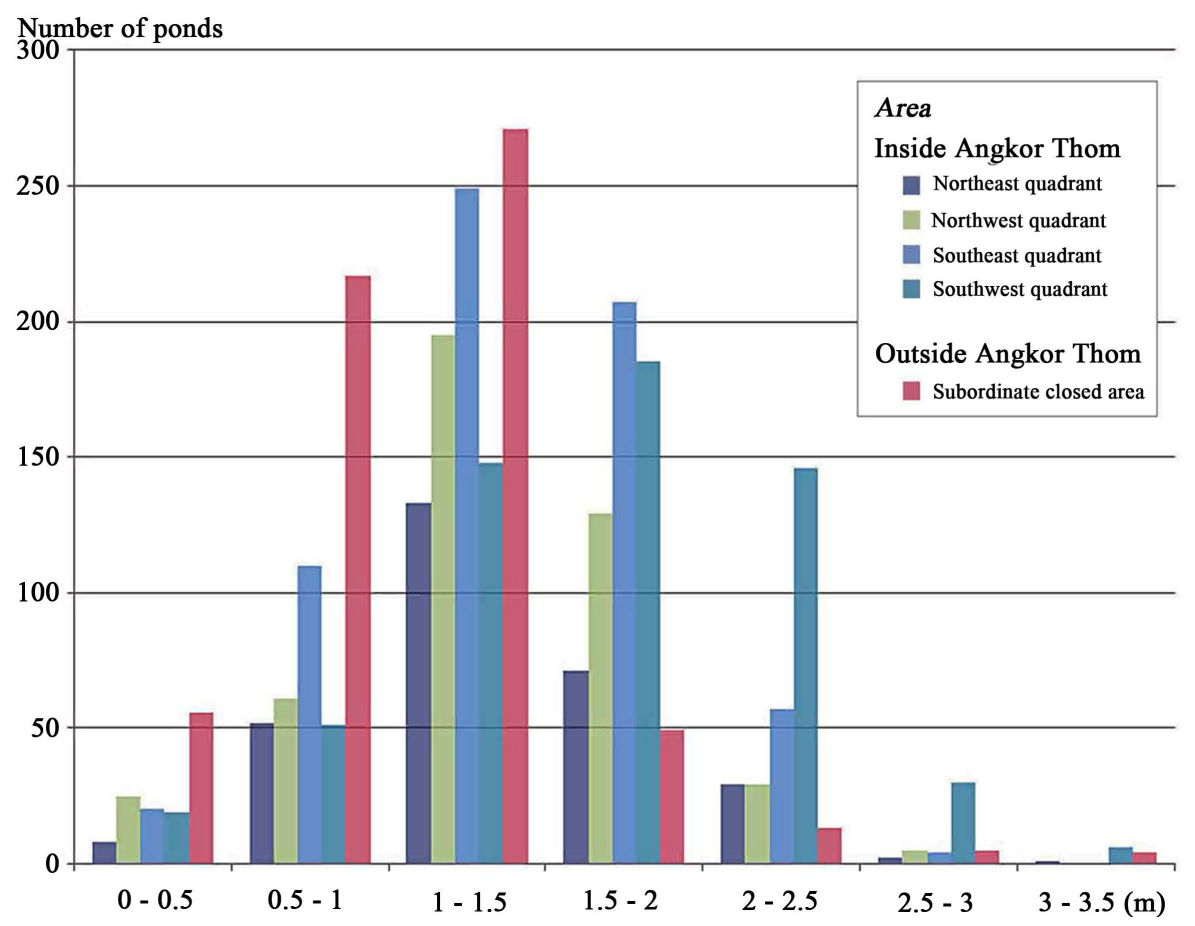

\begin{tabular}{|c|c|c|c|c|c|c|c|c|c|}
\hline & & $0-0.5 \mathrm{~m}$ & $0.5-1 \mathrm{~m}$ & $1-1.5 \mathrm{~m}$ & $1.5-2 \mathrm{~m}$ & $2-2.5 m$ & $2.5-3 \mathrm{~m}$ & $3-3.5 m$ & Total \\
\hline \multirow{5}{*}{$\begin{array}{l}\text { Number of } \\
\text { ponds inside } \\
\text { Angkor } \\
\text { Thom }\end{array}$} & Northeast quadrant & 8 & 52 & 133 & 71 & 29 & 2 & 1 & 296 \\
\hline & Northwest quadrant & 25 & 61 & 195 & 129 & 29 & 5 & 0 & 444 \\
\hline & Southeast quadrant & 20 & 110 & 249 & 207 & 57 & 4 & 0 & 647 \\
\hline & Southwest quadrant & 19 & 51 & 148 & 185 & 146 & 30 & 6 & 585 \\
\hline & Sub-tatal & 72 & 274 & 725 & 592 & 261 & 41 & 7 & 1972 \\
\hline \multicolumn{2}{|c|}{$\begin{array}{l}\text { Number of ponds } \\
\text { in the subordinate closed area }\end{array}$} & 56 & 217 & 271 & 49 & 13 & 5 & 4 & 615 \\
\hline
\end{tabular}


When roughly dividing the royal city into three segments in the east-west direction, the vestiges of water channels and ponds are clear on the west and east sides, but unclear in the central area that is approximately 500 - $800 \mathrm{~m}$ wide (Figure 6). This is possibly due to the fact that the hydraulic structures that initially existed became dysfunctional when the Angkor Empire declined and Angkor Thom was abandoned, and surface water during the rainy seasons became a braided stream that flowed through the central area and destroyed the ponds and water channels.

\section{Remains around the Moated City of Angkor Thom}

Topographical data based on LiDAR revealed with very precise clarity that water channels and ponds were distributed throughout the area outside the moat of Angkor Thom, and in a similar manner as within the royal city (Evans et al., 2013). Trouvé (1933) documented how the east side of the moat of Angkor Thom and East Baray are connected by a water channel, and also recorded numerous remains of linear embankments and water channels in the vicinity of Angkor Thom. Most of the remains identified by Trouvé have been verified by the new topographical data, and is as a testament to Trouvé's careful work.

Groslier identified the existence of a multiple number of water channels that connect to the moat around Angkor Thom, through aerial photos and field exploration (Groslier, 1958). The recently acquired topographical data reveals, however, some of the structures identified by Groslier were presumed restorations based on assumptions. Furthermore, in recent years, archaeological maps of the Angkor area have been updated by Dumarçay \& Pottier (1993), JICA (1998), Pottier (1999) and Evans et al. (2007), and a history of studies of hydraulic structures at the Angkor area has been compiled by Fletcher et al. (2008), but there have been no recent studies that focus on water structure in the vicinity of Angkor Thom. The new topographical data sheds light on the distribution of water channels, embankments and numerous ponds outside Angkor Thom which would imply that the residential community extended beyond the moated city. These structures remain in good condition particularly in the area between Angkor Thom and East Baray, which escaped man-induced intervention owing to the dense forest.

\subsection{Land Allotment Feature inside and outside the Moated City}

Particularly conspicuous among the features in the dense forest between Angkor Thom and East Baray is the embankment that extends to the east from near the southern end of the east side of the moat around Angkor Thom (Trouvé, 1933). This embankment is $4-5 \mathrm{~m}$ high, and extends $1.2 \mathrm{~km}$ to the east before it forms a right angle to the north and continues $350 \mathrm{~m}$ to the southwest corner of the enclosure at Ta Prohm. Because of this structure an area is formed between Angkor Thom and East Baray that is surrounded by water channels that extend east and west and connects with the northeast corner of Angkor Thom, the enclosure of Ta Prohm, the west side of East Baray and the east side of Angkor Thom. A subordinate closed area to Angkor Thom was thus created.

Linear structure remains inside the moated city and this subordinated closed area do not display a continual arrangement. Inside the moated city a dense arrangement of water channels runs east and west, and areas bounded by these water channels are divided into short strips that are wide in the east-west direction, but in the subordinated closed area there are no such longitudinal divisions. Thus, it seems the water channels were installed according to a different system of land allotment inside and outside the moated city, and also points to the possibility that they were installed at different times.

Furthermore, low embankments that are around $3 \mathrm{~m}$ wide and form small square areas which were not found inside the moated city were found in large numbers on the east side of Angkor Thom. It is thought that the embankments were dirt walls that surrounded and separated each house.

\subsection{Ponds in the Subordinate Closed Area to the Angkor Thom}

Ponds in the subordinate closed area have a rectangular plan that matches the cardinal directions like those inside the city, and are around the same sizes. However when compared according to their present landform, the ponds in the subordinated closed area are characteristically shallower than ponds in the city. Many of them are shallower than $1.5 \mathrm{~m}$ (Figure 6, Table 1). It is not certain whether the original depth of the ponds were same inside and outside the city, but the thickness of sedimentary soil is different, or initially the depth of the ponds outside the city were shallower than inside. 
Additionally, they are less densely distributed than the ponds inside the city. There are no ponds to be overlapped with the existed ponds. Although some differences of water environment such as the ground water level and the accessibility to the rivers were estimated between inside and outside the city, these shallower and low density ponds suggest the possibility that the subordinate closed area was home to a residential community for a shorter period than the inside the moated city.

\section{Discussion: Water Management System during the Rainy and Dry Seasons}

The area around the royal capital of Angkor Thom is characterized by clear differences between the rainy and dry seasons. The dry season is from November to April and is a period of little precipitation that is accompanied by temperatures that reach $40^{\circ} \mathrm{C}$. For this reason, there is no doubt that the system for securing and managing water to support the lives of people who live in the royal capital was the most important infrastructural element (Acker, 1998; Fletcher et al., 2008; Groslier, 1979; Kummu, 2003, 2009; Moore, 1995; van Liere, 1980). The rainy season, on the other hand, delivers an abundance of water requiring water to be stored and the excess drained from the flat land inside and outside the royal capital. Based on this background knowledge, the findings that have been acquired about the hydraulic structure of the royal capital of Angkor Thom at the time it was built will be organized, and discussed referencing the new topographical data.

The hydraulic structure of the royal city is based on a mechanism where water flows by gravitational force from the outer to internal linear structure from tunnels that passes through the northern end of the east side of the enclosure, and into the Beng Thom reservoir and drains out to the moat outside the enclosure through the tunnel outlets in the western end of the south side of the enclosure. The northern end of the east side and the western end of the south side are approximately $4 \mathrm{~km}$ apart in a straight-line distance and differ less than $4 \mathrm{~m}$ in elevation (Figure 2). Thus, the natural gradient of the terrain is used to distribute water.

The royal city had a large number of ponds. In the Customs of Cambodia, written by Chou Ta-Kuan, a member of a Chinese mission that visited the royal capital of Yasodarapura (present day Angkor Thom) from 1296 to 1297, the section on "bathing" contains the passage that mentions "a custom of bathing several times a day," and describes how "each house necessarily had a pond, or if not, two to three homes shared a pond." Furthermore, as it is written that "women inside the city go outside the city once in every three to four days of five to six days to bathe in the river," women apparently frequented the Siem Reap River that flows to the east of Angkor Thom. From these passages, it can be assumed that many ponds were needed by each house to pool water for household uses, including bathing, and that the ponds identified in the chronicle correspond to these household ponds. This means that if the number of ponds is 2000 as identified by the RRIM and proposing that a maximum of three houses may have shared a pond, some 6000 houses may have been concentrated within the royal city. By estimating the number of members per household, it is possible to obtain a rough estimate of the city's population.

The ponds probably sufficed as domestic water, but obtaining drinking water would have been problematic. Today, all communities in the rural areas of Cambodia have a pond, and water is drawn from a nearby well using a jug. Deep wells have increased in number in recent years, but most are hand-dug shallow wells that draw free groundwater from a shallow aquifer. Pond water may be contaminated with coliform, but by penetrating through the ground over several meters, it is naturally filtered so that the water that seeps into the well is generally fit for human consumption. Furthermore, it is thought by storing the water in a biscuit-fired jug placed in the shade, the water is cooled by vaporization heat and becomes even more suitable for drinking. Within the living environment of these people, their water environment has possibly remained unchanged since the Angkor Empire period. Thus, it is assumed that people in antiquity also used a well in a similar way to draw free groundwater from a shallow aquifer even though old wells have not yet been found in this area.

The functions of hydraulic facilities in the relatively flat land of Angkor Thom will now be examined. During the rainy season even small depressions fill to over-capacity with rainwater. To lower the water level, it is highly likely that the numerous water channels and ponds provided drainage. If the water channel network was managed and the system functioned to ultimately draw water to Beng Thom via the internal linear structure, it would have been possible to drain water from the city in a relatively short period of time.

During the dry season, it is most important to secure water in the wells. As a drop in water level would lead to well depletion, it is necessary to maintain groundwater level at a certain height (a shallow level from the ground surface). Boring surveys have revealed that the strata inside the royal capital are composed of repeated layers of high permeability sand and clay (Iwasaki et al., 1996). After the rainy season proceeds into the dry season, the 
groundwater level gradually begins to drop. By drawing water from the internal linear structure through the water channel network, water is allowed to penetrate all areas of the royal city via small and large water channels, with water also flowing into the ponds. As the land gradient is extremely gradual, some of the water accumulates in the water channels, and excess water seeps into the ground. The water that flows into the pond and the water that seeps into the ground push up the free groundwater level, and thereby help maintain the water level in the wells.

In these ways, the water channels and ponds are thought to have served differing purposes depending on the seasons. During the rainy season, they were used to promptly drain water, and during the dry season, to maintain the groundwater level.

\section{Summary}

This paper discussed the hydraulic structure inside and outside the Angkor Thom by using the topographical data obtained through a LiDAR survey and expressing it as a high-resolution red relief image map (RRIM). The region is widely covered by a dense forest, but precisely owing to this forest, many areas have escaped human-induced landform alterations which have helped to conserve the structure remains. The topographical map created based on the LiDAR survey provided a large amount of both quantitative and subjective information that could be used within the world geodetic system. Furthermore, in addition to providing an aerial view of the wide distribution of numerous remains that exist as subtle topographical undulations which could not be identified by conventional contour maps, color contour maps and shaded reliefs, the RRIM identified previously obscured water channel structures and artificial ponds inside and outside of Angkor Thom and provided reference for comprehensively analyzing their sizes and layout.

Inside Angkor Thom, the distribution of the water channel structures identified by Gaucher was reconfirmed by the new topographical data, but there were differences in interpretation of the facts concerning some of the water channels and ponds. The initial shape of many of the ponds cannot be distinguished from the present topographical data due to deformation caused by erosion and sedimentation, and many of the later additional ponds were overlapped with adjacent existing ponds.

Around Angkor Thom, it was found that linear water channels were installed according to the cardinal directions in the same manner as those inside, and that there were numerous ponds of the similar sizes as those in the royal city. The distribution of ponds indicates that the residential community extended outside the city. The ponds outside the city were shallower than those inside probably caused by the difference of ground water level and accessibility to the river, or it was thought that the residential community outside the city was abandoned at an early stage and allowed soil and sand to accumulate over a long period of time. Also, while many ponds inside the city appear as though they were dug later in close proximity to each other, no such vestiges have been found to those outside. This also suggested the possibility that outside of the city was used as a residential community for a shorter period of time.

Past Khmer engineers built an advanced water channel system in the Angkor Thom by utilizing the gentle gradient of $0.1 \%$ in the northeast to southwest direction. To promptly drain water during the rainy period, and to maintain the groundwater level during the dry season, they installed a water channel network throughout the royal city as well as outside and dug numerous ponds. The hydraulic structure of Angkor Thom was achieved by their comprehensive knowledge in cleverly utilizing the land form based on their previous experiences in urban planning.

\section{Acknowledgements}

This study was conducted as part of a joint research and conservation project of APSARA and JSA, entitled "Safeguarding of the Bayon Temple of Angkor Thom", directed by Nakagawa Takeshi. The project was supported financially by the UNESCO/Japanese Funds-in-Trust for the Preservation of the World Cultural Heritage and a Grant-in-Aid for Scientific Research from the Japan Society for the Promotion of Science (Project Nos. 25300004 (T. Haraguchi), 21101002 (H. Yonenobu), 23251017 (N. Yamamoto)). We would like to thank Robert McCarthy for his English editing. The authors express their gratitude to HE Bun Narith and HE RosBorath (APSARA National Authority), Jacques Gaucher, Damian Evans, and all the members of the institution of the Khmer Archaeology LiDAR Consortium. 


\section{References}

Acker, R. (1998). New Geographic Tests of the Hydraulic Thesis at Angkor. South East Asia Research, 6, 5-47.

Chiba, T., Kaneta, S., \& Suzuki, Y. (2008). Red Relief Image Map: New Visualization Method for Three Dimensional Data. Remote Sensing and Spatial Information Science, 37, 1071-1076.

Dumarçay, J., \& Pottier, C. (1993). Documents topographiques de la conservation des monuments d'Angkor. Paris: Ecolefrançaised'Extrême-Orient.

Evans, D. et al. (2007). A Comprehensive Archaeological Map of the World's Largest Preindustrial Settlement Complex at Angkor, Cambodia. Proceedings of the National Academy of Sciences of the United States of America, 104, 14277-14282. http://dx.doi.org/10.1073/pnas.0702525104

Evans, D. et al. (2013). Uncovering Archaeological Landscapes at Angkor Using LiDAR. Proceedings of the National Academy of Sciences of the United States of America, 110, 12595-12600. http://dx.doi.org/10.1073/pnas.1306539110

Fletcher, R. et al. (2008). The Water Management Network of Angkor, Cambodia. Antiquity, 82, 658-670. http://dx.doi.org/10.1017/S0003598X00097295

Gaucher, J. (1997). Rapport Champagne 1996-1997, De Yasodharapura à Angkor Thom, Etudes Archéologique à Angkor.

Gaucher, J. (2002). The City of Angkor. What Is It? Museum International, UNESCO, 54, 28-36. http://dx.doi.org/10.1017/S0003598X00097295

Gaucher, J. (2003). Premiersaperçus sur des éléments de planificationurbaine à Angkor Thom. Udaya 4, 41-52.

Gaucher, J. (2004a). Angkor Thom, une utopie réalisée? Structuration de l'espace et modèle indien d'urbanisme dans le Cambodge ancien. Arts Asiatiques, 59, 58-86. http://dx.doi.org/10.3406/arasi.2004.1515

Gaucher, J. (2004b). Schéma Directeur Archéologiqued'Angkor Thom-Document d'evaluation du patrimoineréalizé dans le cadre du programme de recherché. De Yasodharapura à Angkor Thom. Mission archéologiquefrançaise à Angkor Thom.

Glaize, M. (1937). Travaux de recherches, secteur Sud-Est d’Angkor Thom, Prasat N64, Région de Damdek. Bulletin de l'Ecole française d'Extrême-Orient, 37, 635-636.

Goloubew, V. (1933). Le Phnom Bakheng et la ville de Yaçovarman. Bulletin de l'Ecole française d'Extrême-Orient, 33, 319-344. http://dx.doi.org/10.3406/befeo.1933.4624

Goloubew, V. (1934). Nouvelles recherches autour du Phnom Bakheng-Rapport sur une mission archéologique dans la régiond'Ankor (décembre 1933-mars 1934). Bulletin de l'Ecole française d'Extrême-Orient, 34, 576-600. http://dx.doi.org/10.3406/befeo.1934.4981

Goloubew, V. (1936). Recherches dans Ankor Thom, Chronique. Bulletin de l'Ecole française d'Extrême-Orient, 36, 619623.

Goloubew, V. (1937). Recherches de M. Goloubew dans Ankor Thom (Chronique). Bulletin de l'Ecole française d'ExtrêmeOrient, 37, 651-655.

Groslier, B.-P. (1958). Angkor et le Cambodge au XVIe Siècle d'après les sources portugaises et espagnoles. Paris: Presses Universitaires de France (Annales du muséeGuimet, Bibliothèqued’Étude, 63).

Groslier, B.-P. (1979). La cite hydraulique angkorienne: Exploitation ousurexploitation du sol? Bulletin de l'Ecole française d'Extrême-Orient, 66, 161-202. http://dx.doi.org/10.3406/befeo.1979.4014

Iwasaki, Y. et al. (1996). Chap. 4, Geotechnology, Geology, and Environment. In Japanese Government Team for Safeguarding Angkor (Ed.), Annual Report on the Technical Study of Angkor Monument 1996 (pp. 327-382). Japan International Cooperation Center, Tokyo.

JICA (Japan International Cooperation Agency) (1998). 1/5,000, 1/10,000 Topographic Map for Angkor Archaeological Area in Siem Reap Region of the Kingdom of Cambodia.

Kummu, M. (2003). The Natural Environment and Historical Water Management of Angkor, Cambodia. Paper Presented at the 5th World Archaeological Congress, Washington DC, 21-26 June 2003, 27.

Kummu, M. (2009). Water Management of Angkor: Human Impacts on Hydrology and Sediment Transportation. Journal of Environmental Management, 90, 1413-1421. http://dx.doi.org/10.1016/j.jenvman.2008.08.007

Marchal, H. (1918). Monuments secondaires et terrasses bouddhiques d'Angkor Thom. Bulletin de l'Ecole française d'Extrême-Orient, 18, 1-40. http://dx.doi.org/10.3406/befeo.1918.5898

Marchal, H. (1925). Notes sur le Palais Royal d’Angkor Thom. AAK, 2, 303-328.

Moore, E. M. (1995). The Waters of Angkor. Asian Arts and Culture, 8, 37-52.

Mori, Y. (2012). Palaeoenvironment of the Areas Surrounding the Angkor Thom Moat Inferred from Entomological Analysis. In Y. Yasuda (Ed.), Water Civilization (pp. 383-404). Tokyo: Springer Japan. 
Pottier, C. (1999). Carte Archéologique de la Régiond’Angkor.Zone sud. Unpublished PhD Thesis, Paris: Universite Paris III, Sorbonne Nouvelle.

Trouvé, G. (1933). Chaussées et canaux autour d'Angkor Thom (Chronique). Bulletin de l'Ecole française d'Extrême-Orient, 33, 1120-1128.

Van Liere, W. J. (1980). Traditional Water Management in the Lower Mekong Basin. World Archaeology, 11, $265-280$. http://dx.doi.org/10.1080/00438243.1980.9979766

Yokoyama, R., Sirasawa, M., \& Pike, R. (2002). Visualizing Topography by Openness: A New Application of Image Processing to Digital Elevation Models. Photogrammetric Engineering and Remote Sensing, 68, 257-265. 